\title{
EVALUATIVE BIBLIOMETRIC ANALYSIS OF RECENT TRENDS IN RURAL TOURISM LITERATURE
}

\author{
Miljan Leković ${ }^{1}$, Drago Cvijanović ${ }^{2}$, Nemanja Pantić3, Tanja Stanišićc ${ }^{4}$ \\ *Corresponding authorE-mail:m.lekovic@kg.ac.rs
}

\begin{tabular}{l} 
A R T I C L E I N F O \\
Original Article \\
Received: 25 August 2020 \\
Accepted: 08 December 2020 \\
doi:10.5937/ekoPolj2004265L \\
UDC 02:338.48-44(1-22) \\
\hline
\end{tabular}

Keywords:

rural tourism, evaluative bibliometric analysis, Web of Science, tourism journals

JEL: Z30, Z32

\begin{abstract}
A B S T R A C T
The development of academic thought is a slow but unquestionable process that leads to a more advanced intellectual structure of the research area. The global growth of tourism demand in rural areas has conditioned the accelerated development of rural tourism, and thus the growing interest of the academic community in this tourism specialism. In this regard, the paper aims to provide insight into recent trends in rural tourism literature and examine the intellectual structure of this discipline. A detailed review of relevant literature published in the Web of Science (WoS) tourism journals and the application of evaluative bibliometric analysis identified the predominant interests of authors and dominant research niches, the most common research regions, the most frequently used research methods, papers that had the highest impact on modelling scientific thought within the subject area, the most productive and influential journals, as well as the authors who have left the most profound trace in the analyzed discipline in the past ten years. It is expected that the paper stimulates academic discussion on the relatively steady interest of researchers and the need for further and more dynamic intellectual development in the field of rural tourism.
\end{abstract}

(C) 2020 EA. All rights reserved.

1 Miljan Leković, Ph.D., Assistant Professor, University of Kragujevac, Faculty of Hotel Management and Tourism in Vrnjačka Banja, Vojvođanska 5A, 36210 Vrnjačka Banja, Serbia. Phone: +381 6435823 04. E-mail: m.lekovic@kg.ac.rs. ORCID ID (https://orcid.org/00000002-4952-3991)

2 Drago Cvijanović, Ph.D., Full Professor, University of Kragujevac, Faculty of Hotel Management and Tourism in Vrnjačka Banja, Vojvođanska 5A, 36210 Vrnjačka Banja, Serbia. Phone: +381 63 295 111. E-mail: dvcmmv@gmail.com. ORCID ID (https://orcid.org/0000-0002-4037-327X)

3 Nemanja Pantić, Ph.D., Teaching Assistant, University of Kragujevac, Faculty of Hotel Management and Tourism in Vrnjačka Banja, Vojvođanska 5A, 36210 Vrnjačka Banja, Serbia. Phone: +381 612058 758. E-mail: nemanja.pantic@kg.ac.rs. ORCID ID (https://orcid.org/00000003-0030-6950)

4 Tanja Stanišić, Ph.D., Associate Professor, University of Kragujevac, Faculty of Hotel Management and Tourism in Vrnjačka Banja, Vojvođanska 5A, 36210 Vrnjačka Banja, Serbia. Phone: +381 6449415 42. E-mail: tanja.stanisic@kg.ac.rs. ORCID ID (https://orcid.org/00000001-5809-794X) 


\section{Introduction}

Rural areas in the last decade are going through a global crisis, as the traditional rural way of life is slowly disappearing, so the development of tourism in these areas is crucial for its preservation and prevention of assimilation with the urban lifestyle (Gao \& Wu, 2017). Thus, rural tourism relies on rural "backwardness" in terms of authenticity and history, however, in the same time, it is a factor of the development and modernization of rural areas (Hjalager et al., 2018).

There is no universal definition of rural tourism, however, based on the existing literature in the field, it is commonly stated that rural tourists visit rural areas motivated by a desire for cultural and historical heritage (Blažević et al., 2018), by experiencing nature and acquaintance of local population and their customs (Cvijanović et al., 2017b; Hjalager et al., 2018) and in regard with several other reasons. Laureiro (2014) argue that rural tourism is inspired not only by the natural characteristics of the rural area but also by a whole array of accompanying "activities" (history, culture, food, customs). In contrast, some authors (Cvijanović et al., 2017a; Devesa et al., 2010) consider that the natural characteristics of the rural areas are the only important factor in the development of this type of tourism. The narrower understanding of rural tourism is also accepted by Martín and Hererro (2012), emphasizing that the central motivating moment for this type of tourism is direct contact with the rural way of life.

Park et al. (2015), point out that rural tourism is only an alternative activity in rural areas where traditional economic activities have not taken root. On the other hand, Philips et al. (2013) state that the development of rural tourism complements traditional agricultural production and reduces the risk of uncertainty of agricultural yields as the dominant source of income, which leads to faster development of rural areas. The development of rural tourism is not only a matter of local character but is a subject of broader interest (regional and national), because it generates employment and increases state revenues (Rid et al., 2014). "Rural tourism is an agent of change and an important factor of economic development with the potential to reduce the gap between rich and poor" (Su et al. 2019, p. 272) and to ensure a more even distribution of national income.

Based on the above mentioned, this paper aims to deploy bibliometric analysis of contemporary Web of Science (WoS) literature on rural tourism, to point out recent trends expressed and monitored by the academic community in terms of subject, geographical area and research methodology, as well as to identify scientific journals, papers and authors who have made the most significant contribution to modelling scientific thought within the research area in the past decade.

\section{Materials and methods}

Following the example of numerous papers in the field of tourism (Evren \& Kozak, 2013; Hall, 2011; Koseoglu et al., 2016; Nusair et al., 2019), the research was grounded on evaluative bibliometric analysis that provides an objective insight into the intellectual structure of a particular area. Harzing's Publish or Perish 6.45 software was used to 
conduct the bibliometric analysis. In the first step, this software was used to search for papers using keyword 'rural tourism'. The software search resulted in an initial output of 200 bibliographic items, which was then filtered by enclosing: 1) papers published in the period 2010-2019 in WoS tourism journals; 2) papers designated as an original scientific paper, review scientific paper or case study (research notes, conference reports, commentaries, research letters and editorials are omitted), 3) papers that have achieved ten or more Scopus citation per year. By applying the criteria mentioned above, a final sample of 27 papers was formed, later on, divided into two comparative five-year periods (2010-2014 and 2015-2019) to monitor the development of theoretical thought and the discipline of rural tourism in general.

In the second step, an annotated literature review was performed for each of the mentioned subperiods in order to come up into the current interests of the authors and the essence of the researched area, all in order to better understand the prevailing trends and possible directions of further development of this tourism specialism. Then, the analysis of key words was followed, which, for the sake of clear visualization of the dominant research niches, was presented not only by a spreadsheet but also by word cloud. At the same time, with an aim to compare the interests of the authors, the representation of the prevailing themes within the two comparative subperiods was examined. Finally, in addition to keyword analysis, citation analysis (specifically, Google Scholar and Scopus citation analysis) was conducted as a reliable indicator of the impact of the papers and the authoritativeness of the authors. It is essential to point out here that Scopus citations carry more weight since scientific journals are subject to strict control and quality analysis when referring to the Scopus index database. At the same time, Google Scholar operates on the principle of free and uncontrolled access. Also, Google Scholar is often characterized by duplicate entries, incomplete metadata, and the presence of non-scholarly publications (Martín-Martín et al., 2018), which can create a distorted picture of the citation and significance of individual papers. Nevertheless, the inclusion of this database is justified by the fact that it provides extra coverage of relevant literature compared to the Scopus index database, and therefore provides a broader picture of the researched issues.

\section{Results and discussion}

\section{Search results and review of contemporary rural tourism literature}

This paper examines the WoS literature on the topic of rural tourism published within the ongoing decade (2010-2019). For the purpose of comparative analysis, the selected papers were divided into papers published in the period 2010-2014 (Table 1) and papers published in the period 2015-2019 (Table 2). In addition to the basic metadata, the regions in which the research was conducted, as well as the methodology applied in the research are recorded in Tables 1 and 2.

Within the first five-year period, the following papers and questions to which the authors offered answers were singled out. Látková and Vogt (2012) examined the attitude of 
the local population regarding tourism development and found that it is crucial for the development of the tourism industry. The results of the survey showed that the local population has a positive attitude towards tourism development. Devesa et al. (2010) examined the relationship between satisfaction and motivation of rural tourists on the example of one rural area in Spain concluding that satisfaction, although it is found as most important, is not the sole motivating factor. Different groups of tourists are motivated by different contents. The limitation of their research to one rural area prevents generalization, however, it provides some guidelines to managers on which specific attributes they must focus on to attract tourists (natural environment, cultural and historical heritage, well-marked hiking routes). Also, the creation of a unique, internationally acceptable questionnaire on the topic of tourist satisfaction is, in the opinion of the author, a challenge to strive for.

The issue of tourist satisfaction was also addressed by Loureiro and Kastenholz (2011). On the example of tourists from rural areas in Portugal, they concluded that satisfaction is related to the reputation of the site, where managers are crucial who must emphasize the production of autochthonous food and organization of cultural events in which tourists are particularly interested. Similarly, almost identical conclusions were reached by Philips et al. (2013) who examined the satisfaction of tourists as a factor in revisiting a tourist place. In addition, managers must be aware of the fact that the sale of arrangements depends on the innovation of online sales and the simplicity of the transaction realization since the standard way of booking is replaced by online purchase of arrangements (Martin \& Herrero, 2012). In her second paper on this topic, Loureiro (2014) upgraded her previous research and concluded that the reputation of a locality depends on the degree of excitement that will affect a memorable experience of the place, and consequently attract tourists.

Rid et al. (2014) noticed the necessity of segmentation of the tourist market, which must be based on the wishes of tourists. Tourists rarely visit a tourist destination driven by a desire for a spiritual experience, although, according to research conducted by Sharpley and Jepson (2011), it can make a significant contribution to overall satisfaction. In addition, tourism development, with respect to satisfaction and wishes of tourists, is not possible without its social component. This issue has been addressed by Zhao et al. (2011), as they have highlighted its importance. The same authors focused their attention on an urge to acquaint the local population with the benefits of tourism, that was additionally confirmed within the Park et al. (2012) study as well. According to Mbaiwa and Stronza (2010), tourism development in rural areas will raise the living standard of the population faster than in communities that have already achieved a certain level of economic growth. 
Table 1. Search results for rural tourism literature published in WoS tourism journals in the period 2010-2014

\begin{tabular}{|c|c|c|c|c|}
\hline Author(s) & Title & Journal & Region & Method(s) \\
\hline $\begin{array}{l}\text { Devesa, M., } \\
\text { Laguna, M., } \\
\text { \& Palacios, A. } \\
\text { (2010) }\end{array}$ & $\begin{array}{l}\text { "The role of motivation in } \\
\text { visitor satisfaction: Empirical } \\
\text { evidence in rural tourism" }\end{array}$ & $\begin{array}{c}\text { Tourism } \\
\text { Management }\end{array}$ & Spain & $\begin{array}{l}\text { ANOVA, factor and } \\
\text { cluster analyses }\end{array}$ \\
\hline $\begin{array}{l}\text { Látková, P., } \\
\text { \& Vogt, C. A. } \\
\text { (2012) }\end{array}$ & $\begin{array}{l}\text { "Residents' attitudes toward } \\
\text { existing and future tourism } \\
\text { development in rural } \\
\text { communities" }\end{array}$ & $\begin{array}{l}\text { Journal of Travel } \\
\text { Research }\end{array}$ & I & $\begin{array}{l}\text { Tourism Area Life } \\
\text { Cycle (TALC) } \\
\text { model }\end{array}$ \\
\hline $\begin{array}{l}\text { Loureiro, S. M. } \\
\text { C., \& Kastenholz, } \\
\text { E. }(2011)\end{array}$ & $\begin{array}{c}\text { "Corporate reputation, } \\
\text { satisfaction, delight, and } \\
\text { loyalty towards rural lodging } \\
\text { units in Portugal" }\end{array}$ & $\begin{array}{c}\text { International } \\
\text { Journal of } \\
\text { Hospitality } \\
\text { Management }\end{array}$ & Portugal & $\begin{array}{c}\text { Partial least squares- } \\
\text { structural equation } \\
\text { modeling (PLS- } \\
\text { SEM) }\end{array}$ \\
\hline $\begin{array}{l}\text { Loureiro, S. M. } \\
\text { C. }(2014)\end{array}$ & $\begin{array}{c}\text { "The role of the rural tourism } \\
\text { experience economy in place } \\
\text { attachment and behavioral } \\
\text { intentions" }\end{array}$ & $\begin{array}{c}\text { International } \\
\text { Journal of } \\
\text { Hospitality } \\
\text { Management }\end{array}$ & Portugal & $\begin{array}{c}\text { Partial least squares- } \\
\text { structural equation } \\
\text { modeling (PLS- } \\
\text { SEM) }\end{array}$ \\
\hline $\begin{array}{l}\text { Martín, H. S., } \\
\text { \& Herrero, Á. } \\
\quad \text { (2012) }\end{array}$ & $\begin{array}{l}\text { "Influence of the user's } \\
\text { psychological factors on the } \\
\text { online purchase intention in } \\
\text { rural tourism: Integrating } \\
\text { innovativeness to the UTAUT } \\
\text { framework" } \\
\end{array}$ & $\begin{array}{c}\text { Tourism } \\
\text { Management }\end{array}$ & Spain & $\begin{array}{l}\text { Unified Theory of } \\
\text { Acceptance and } \\
\text { Use of Technology } \\
\text { (UTAUT) }\end{array}$ \\
\hline $\begin{array}{l}\text { Mbaiwa, J. E. \& } \\
\text { Stronza, A. L. } \\
\quad(2010)\end{array}$ & $\begin{array}{c}\text { "The effects of tourism } \\
\text { development on rural } \\
\text { livelihoods in the Okavango } \\
\text { Delta, Botswana" }\end{array}$ & $\begin{array}{l}\text { Journal of } \\
\text { Sustainable } \\
\text { Tourism }\end{array}$ & Botswana & Case study \\
\hline $\begin{array}{c}\text { Park, D.-B., Lee, } \\
\text { K-W., Choi, H-S., } \\
\text { \& Yoon, Y.-S. } \\
(2012) \\
\end{array}$ & $\begin{array}{l}\text { "Factors influencing social } \\
\text { capital in rural tourism } \\
\text { communities in South Korea" }\end{array}$ & $\begin{array}{c}\text { Tourism } \\
\text { Management }\end{array}$ & $\begin{array}{l}\text { South } \\
\text { Korea }\end{array}$ & $\begin{array}{l}\text { Binary logistic } \\
\text { regression model }\end{array}$ \\
\hline $\begin{array}{l}\text { Phillips, W., } \\
\text { Wolfe, K., Hodur, } \\
\text { N., \& Leistritz, F. } \\
\text { L. (2013) } \\
\end{array}$ & $\begin{array}{l}\text { "Tourist word of mouth and } \\
\text { revisit intentions to rural } \\
\text { tourism destinations: A case } \\
\text { of North Dakota, USA" }\end{array}$ & $\begin{array}{c}\text { International } \\
\text { Journal of } \\
\text { Tourism Research }\end{array}$ & USA & Case study \\
\hline $\begin{array}{c}\text { Rid, W., } \\
\text { Ezeuduji, I. O., } \\
\text { \& Pröbstl-Haider, } \\
\text { U. (2014) } \\
\end{array}$ & $\begin{array}{c}\text { "Segmentation by motivation } \\
\text { for rural tourism activities in } \\
\text { The Gambia" }\end{array}$ & $\begin{array}{c}\text { Tourism } \\
\text { Management }\end{array}$ & Gambia & $\begin{array}{l}\text { ANOVA and factor } \\
\text { analyses }\end{array}$ \\
\hline $\begin{array}{c}\text { Sharpley, R., \& } \\
\text { Jepson, D. (2011) }\end{array}$ & $\begin{array}{c}\text { "Rural tourism: A spiritual } \\
\text { experience?" }\end{array}$ & $\begin{array}{c}\text { Annals of } \\
\text { Tourism Research } \\
\end{array}$ & England & No specific method \\
\hline $\begin{array}{c}\text { Zhao, W., } \\
\text { Ritchie, J. R. B., } \\
\text { \& Echtner, C. M. } \\
\text { (2011) }\end{array}$ & $\begin{array}{c}\text { "Social capital and tourism } \\
\text { entrepreneurship" }\end{array}$ & $\begin{array}{c}\text { Annals of } \\
\text { Tourism Research }\end{array}$ & l & No specific method \\
\hline
\end{tabular}

Source: Author's research 
Within the second five-year period, the paper which analysis will provide insight into even more recent trends and comparison with the previously analyzed period were singled out. According to Campón-Cerro et al. (2017), a decade behind us is characterized by a steady increase in tourism demand in rural areas. One of the reasons is the increased marketing activity and the ability of managers to create such an offer that will not only satisfy the tourist expectations but also make him a loyal guest. Loyalty is also achieved by realizing the expectations of tourists, which is not an easy task and shows that a positive experience has a positive correlation with loyalty (Kastenholz et al., 2018). However, loyalty is not only affected by a positive experience, but it depends on several factors: connection with the local population, local food, local beer and others (Murray \& Kline, 2015). Frisvoll et al. (2015) indicated that a limited number of studies on the impact of local food on tourism development. In addition, in their research, they concluded that $25 \%$ of tourists singled out food as the most crucial factor in choosing a particular destination. According to Sidali et al. (2015), the specificity of local food is vital in attracting tourists, but insufficient marketing activity reduces promotion through local food to the experiences of previous tourists. It is essential to point out that the connection with the local population is a subject of mutual interest, given that good relation with tourists positively affect the pride of the local population and have positive effects on the quality of life (Xue et al., 2017). The pride of the local population is so pronounced that they are more willing to non-economic than economic assistance (Strzelecka et al., 2017). The economic benefits, i.e. the possibilities of earning from tourism, are apparent, but tourism is still an activity in which the more affluent layers of society are mostly involved. Tourism does not have a significant share in income generation for that part of the population that cannot be included in that group ( $\mathrm{Su}$ et al., 2019). According to Wang and Yotsumoto (2019), not only there is not enough interest in entrepreneurial activity, but a whole range of administrative problems related to the preservation of cultural heritage makes entrepreneurial intentions challenging to realize. For this reason, there is a "conflict" of residents with local authorities, because they demand the distribution of income from tourism, although they do not participate in its creation.

Rural tourism is one of the main factors of rural development - a fact that is not given a deserved place (Gao \& Wu, 2017). For the concept of rural tourism to take place it deserves, local and public authorities must support it in terms of investment activity, that will eventually lead to launching a whole range of activities and industries. One of the necessary items is undoubtedly innovation in the broadest sense of the word. However, there is a cost-effectiveness problem that is realistic in the long run. It is often the case that there is no interest or time for this long term (Hjalager et al., 2018). The importance of state intervention was also emphasized by Lane and Kastenholz (2015) in their case study. However, the peripheries have rarely been part of national tourism policies. Therefore, the transition and revision of the same are necessary for tourism in rural areas has received a deserved place (Salvatore et al., 2018). An analysis of the importance of rural tourism development was also performed by Rasoolimanesh 
et al. (2017a) based on the attitudes of the local rural population. The analysis gave conflicting views which are conditioned by the economic gains from tourist visits. Those directly involved in the tourism offer had a positive attitude, while those who were not included in the offer had a negative one. Rasoolimanseh et al. (2017b) conducted a similar study on the example of residents of urban destinations arguing that a unique positive attitude of those directly and indirectly involved in the tourism industry. On the other hand, Park et al. (2015) emphasizing the rarity of research dealing with the impact of social capital on the development of rural tourism, concluded that it is important how residents perceive the socio-economic impacts of tourism. Residents' support of the rural tourism development depends on the adequacy of the management of the negative consequences of social capital.

Table 2. Search results for rural tourism literature published in WoS tourism journals in the period 2015-2019

\begin{tabular}{|c|c|c|c|c|}
\hline Author(s) & Title & Journal & Region & Method(s) \\
\hline $\begin{array}{l}\text { Campón- } \\
\text { Cerro, A. M., } \\
\text { Hernández- } \\
\text { Mogollón, J. } \\
\text { M., \& Alves, H. } \\
\text { (2017) }\end{array}$ & $\begin{array}{l}\text { "Sustainable improvement } \\
\text { of competitiveness in rural } \\
\text { tourism destinations: The } \\
\text { quest for tourist loyalty in } \\
\text { Spain" }\end{array}$ & $\begin{array}{l}\text { Journal of } \\
\text { Destination } \\
\text { Marketing and } \\
\text { Management }\end{array}$ & Spain & $\begin{array}{c}\text { Partial least } \\
\text { squares- } \\
\text { structural equation } \\
\text { modeling (PLS- } \\
\text { SEM) }\end{array}$ \\
\hline $\begin{array}{l}\text { Frisvoll, S., } \\
\text { Forbord, M., \& } \\
\text { Blekesaune, A. } \\
\text { (2016) }\end{array}$ & $\begin{array}{l}\text { "An empirical investigation } \\
\text { of tourists" consumption of } \\
\text { local food in rural tourism" }\end{array}$ & $\begin{array}{l}\text { Scandinavian } \\
\text { Journal of } \\
\text { Hospitality and } \\
\text { Tourism }\end{array}$ & Norway & $\begin{array}{l}\text { Questionnaire } \\
\text { techniques }\end{array}$ \\
\hline $\begin{array}{c}\text { Gao, J., \& Wu, B. } \\
\text { (2017) }\end{array}$ & $\begin{array}{l}\text { "Revitalizing traditional } \\
\text { villages through rural } \\
\text { tourism: A case study of } \\
\text { Yuanjia Village, Shaanxi } \\
\text { Province, China" } \\
\end{array}$ & $\begin{array}{c}\text { Tourism } \\
\text { Management }\end{array}$ & China & Case study \\
\hline $\begin{array}{c}\text { Hjalager, A., } \\
\text { Kwiatkowski, G., } \\
\text { \& Larsen, M. Ø. } \\
\text { (2018) }\end{array}$ & $\begin{array}{l}\text { "Innovation gaps in } \\
\text { Scandinavian rural tourism" }\end{array}$ & $\begin{array}{l}\text { Scandinavian } \\
\text { Journal of } \\
\text { Hospitality and } \\
\text { Tourism }\end{array}$ & $\begin{array}{c}\text { Scandinavia } \\
\text { (Denmark, } \\
\text { Norway and } \\
\text { Sweden) }\end{array}$ & Case study \\
\hline $\begin{array}{l}\text { Kastenholz, E., } \\
\text { Carneiro, M. J., } \\
\text { Marques, C. P., \& } \\
\text { Loureiro, S. M. } \\
\text { C. (2018) }\end{array}$ & $\begin{array}{l}\text { "The dimensions of rural } \\
\text { tourism experience: Impacts } \\
\text { on arousal, memory, and } \\
\text { satisfaction" }\end{array}$ & $\begin{array}{c}\text { Journal of Travel } \\
\text { and Tourism } \\
\text { Marketing }\end{array}$ & Portugal & $\begin{array}{l}\text { Tourist Experience } \\
\text { Scale - TES }\end{array}$ \\
\hline $\begin{array}{l}\text { Lane, B., \& } \\
\text { Kastenholz, E. } \\
\quad(2015)\end{array}$ & $\begin{array}{l}\text { "Rural tourism: The } \\
\text { evolution of practice and } \\
\text { research approaches - } \\
\text { towards a new generation } \\
\text { concept?" }\end{array}$ & $\begin{array}{l}\text { Journal of } \\
\text { Sustainable } \\
\text { Tourism }\end{array}$ & I & $\begin{array}{l}\text { No specific } \\
\text { method }\end{array}$ \\
\hline $\begin{array}{c}\text { Murray, A., \& } \\
\text { Kline, C. (2015) }\end{array}$ & $\begin{array}{l}\text { "Rural tourism and the craft } \\
\text { beer experience: Factors } \\
\text { influencing brand loyalty in } \\
\text { rural North Carolina, USA" }\end{array}$ & $\begin{array}{l}\text { Journal of } \\
\text { Sustainable } \\
\text { Tourism }\end{array}$ & USA & Case study \\
\hline
\end{tabular}




\begin{tabular}{|c|c|c|c|c|}
\hline Author(s) & Title & Journal & Region & Method(s) \\
\hline $\begin{array}{l}\text { Park, D.-B., } \\
\text { Nunkoo, R., } \\
\text { \& Yoon, Y.-S. } \\
\text { (2015) }\end{array}$ & $\begin{array}{l}\text { "Rural residents' attitudes to } \\
\text { tourism and the moderating } \\
\text { effects of social capital" }\end{array}$ & $\begin{array}{c}\text { Tourism } \\
\text { Geographies }\end{array}$ & $\begin{array}{l}\text { South } \\
\text { Korea }\end{array}$ & $\begin{array}{l}\text { Multi-group } \\
\text { analysis }\end{array}$ \\
\hline $\begin{array}{l}\text { Rasoolimanesh, } \\
\text { S. M., Roldan, } \\
\text { J. L., Jaafar, M., } \\
\text { \& Ramayah, T. } \\
\text { (2017a) }\end{array}$ & $\begin{array}{l}\text { "Factors influencing } \\
\text { residents' perceptions toward } \\
\text { tourism development: } \\
\text { Differences across rural and } \\
\text { urban world heritage sites" }\end{array}$ & $\begin{array}{c}\text { Journal of Travel } \\
\text { Research }\end{array}$ & Malaysia & $\begin{array}{c}\text { Partial least } \\
\text { squares- } \\
\text { structural equation } \\
\text { modeling (PLS- } \\
\text { SEM) } \\
\end{array}$ \\
\hline $\begin{array}{l}\text { Rasoolimanesh, } \\
\text { S. M., Ringle, C. } \\
\text { M., Jaafar, M., } \\
\text { \& Ramayah, T. } \\
\text { (2017b) }\end{array}$ & $\begin{array}{l}\text { "Urban vs. rural destinations: } \\
\text { Residents' perceptions, } \\
\text { community participation } \\
\text { and support for tourism } \\
\text { development" }\end{array}$ & $\begin{array}{c}\text { Tourism } \\
\text { Management }\end{array}$ & Malaysia & $\begin{array}{c}\text { Partial least } \\
\text { squares- } \\
\text { structural equation } \\
\text { modeling (PLS- } \\
\text { SEM) }\end{array}$ \\
\hline $\begin{array}{c}\text { Salvatore, R., } \\
\text { Chiodo, E., \& } \\
\text { Fantini, A. (2018) }\end{array}$ & $\begin{array}{c}\text { "Tourism transition in } \\
\text { peripheral rural areas: } \\
\text { Theories, issues and } \\
\text { strategies" }\end{array}$ & $\begin{array}{c}\text { Annals of } \\
\text { Tourism Research }\end{array}$ & Italy & Cluster analysis \\
\hline $\begin{array}{l}\text { Sidali, K., L., } \\
\text { Kastenholz, E., } \\
\text { \& Bianchi, R. } \\
\text { (2015) }\end{array}$ & $\begin{array}{l}\text { "Food tourism, niche markets } \\
\text { and products in rural tourism: } \\
\text { Combining the intimacy } \\
\text { model and the experience } \\
\text { economy as a rural } \\
\text { development strategy" } \\
\end{array}$ & $\begin{array}{l}\text { Journal of } \\
\text { Sustainable } \\
\text { Tourism }\end{array}$ & I & $\begin{array}{l}\text { No specific } \\
\text { method }\end{array}$ \\
\hline $\begin{array}{l}\text { Strzelecka, M., } \\
\text { Boley, B. B., \& } \\
\text { Strzelecka, C } \\
\quad \text { (2017) }\end{array}$ & $\begin{array}{l}\text { "Empowerment and resident } \\
\text { support for tourism in } \\
\text { rural Central and Eastern } \\
\text { Europe (CEE): The case of } \\
\text { Pomerania, Poland" } \\
\end{array}$ & $\begin{array}{l}\text { Journal of } \\
\text { Sustainable } \\
\text { Tourism }\end{array}$ & Poland & $\begin{array}{l}\text { Structural equation } \\
\text { modeling (SEM) }\end{array}$ \\
\hline $\begin{array}{l}\text { Su, M. M., Wall, } \\
\text { G., Wang, Y., \& } \\
\text { Jin, M. (2019) }\end{array}$ & $\begin{array}{c}\text { "Livelihood sustainability in } \\
\text { a rural tourism destination - } \\
\text { Hetu Town, Anhui Province, } \\
\text { China" }\end{array}$ & $\begin{array}{c}\text { Tourism } \\
\text { Management }\end{array}$ & China & Case study \\
\hline $\begin{array}{c}\text { Wang, L., \& } \\
\text { Yotsumoto, Y. } \\
(2019) \\
\end{array}$ & $\begin{array}{c}\text { "Conflict in tourism } \\
\text { development in rural China" }\end{array}$ & $\begin{array}{c}\text { Tourism } \\
\text { Management }\end{array}$ & China & $\begin{array}{l}\text { No specific } \\
\text { method }\end{array}$ \\
\hline $\begin{array}{c}\text { Xue, L., } \\
\text { Kerstetter, D., \& } \\
\text { Hunt, C. (2017) }\end{array}$ & $\begin{array}{l}\text { "Tourism development and } \\
\text { changing rural identity in } \\
\text { China" }\end{array}$ & $\begin{array}{c}\text { Annals of } \\
\text { Tourism Research }\end{array}$ & China & Case study \\
\hline
\end{tabular}

Source: Author's research

Based on the above mentioned, the following conclusions can be drawn. In the literature review related to the period 2010-2014, the papers dealing with the loyalty and satisfaction of tourists are the most common. The conclusions reached by the authors are almost identical, even though the analyses are territorially separate. The period after 2014 was marked by papers on a similar topic. Thus, the interest of the authors in both comparative periods is mainly focused on the satisfaction of tourists and the creation of their loyalty with an emphasis on the role of managers and their knowledge 
and skills to make the destination attractive. However, the papers that, in addition to tourism demand, are focused on the offer side and in which the emphasized role of the state as a necessary subject in the development of rural tourism and its intervention can be seen, can also be found. It is important to note that there is a lack of studies dealing with comparative analysis of the development of rural tourism in different areas, which should undoubtedly be an inspiration to future authors of papers in this field.

A comparative analysis of Table 1 and Table 2 also indicates that most surveys (36\%) in the first subperiod were conducted in Spain and Portugal, while China dominated as the host country of the survey $(25 \%)$ in the second subperiod. This finding suggests the gradual shifting of the interests of researchers in the field of rural tourism from European countries to Asian countries. Finally, the first subperiod was dominated by three research methods: Partial least squares - structural equation modelling (PLSSEM) technique, Case study and ANOVA and factor analyses with an individual share of $18 \%$ and cumulative of $55 \%$, while Case study method doubled its participation in the second subperiod, PLS-SEM technique retained the same participation, and ANOVA and factor analyses were not applied in any research.

\section{Results of evaluative bibliometric analysis}

The papers on the topic of rural tourism described in the previous subtitle, selected by searching the WoS tourism journals, served as a sample for conducting an evaluative bibliometric analysis. In the first step, the journal distribution of the papers was proposed, to single out the most productive WoS tourism journals in the context of the research area (Table 3).

Table 3. The distribution of the papers across the journals

\begin{tabular}{|c|c|c|c|}
\hline Journal & $\begin{array}{c}\text { Number of the } \\
\text { papers }\end{array}$ & $\mathbf{2 0 1 0 - 2 0 1 4}$ & $\mathbf{2 0 1 5 - 2 0 1 9}$ \\
\hline Tourism Management & 8 & 4 & 4 \\
\hline Journal of Sustainable Tourism & 5 & 1 & 4 \\
\hline Annals of Tourism Research & 4 & 2 & 2 \\
\hline Journal of Travel Research & 2 & 1 & 1 \\
\hline International Journal of Hospitality Management & 2 & 2 & 0 \\
\hline Scandinavian Journal of Hospitality and Tourism & 2 & 0 & 2 \\
\hline Journal of Destination Marketing and Management & 1 & 0 & 1 \\
\hline International Journal of Tourism Research & 1 & 1 & 0 \\
\hline Journal of Travel and Tourism Marketing & 1 & 0 & 1 \\
\hline Tourism Geographies & 1 & 0 & 1 \\
\hline Total & 27 & 11 & 16 \\
\hline
\end{tabular}

Source: Author's research

The analysis determined the dominant share of the scientific journal Tourism Management, which participates in the total production of sampled papers with $30 \%$. At the same time, a high degree of concentration of papers is evident, since $63 \%$ of the selected papers were published in only three journals: Tourism Management, Journal 
of Sustainable Tourism and Annals of Tourism Research. It should be noted that the distribution of papers across two comparative periods is uniform in the case of Tourism Management and Annals of Tourism Research, while the Journal of Sustainable Tourism records significantly higher production of papers in the field of rural tourism in the last five years, which indicates to the potentially greater importance of this journal for the subject area in the coming period.

In the continuation of the bibliometric analysis, the analysis of keywords was conducted in order to determine the dominant topics and issues that occupy the attention of researchers (Table 4). A total of 170 keywords were singled out from individual papers, where only keywords that were repeated three or more times are shown in a table, and different words of the same meaning are recorded as a one.

Table 4. The most commonly used keywords within the sample

\begin{tabular}{|c|c|c|c|}
\hline Keyword & $\begin{array}{c}\text { Number of } \\
\text { repetitions }\end{array}$ & $\mathbf{2 0 1 0 - 2 0 1 4}$ & $\mathbf{2 0 1 5 - 2 0 1 9}$ \\
\hline rural tourism & 19 & 8 & 11 \\
\hline (tourism) development & 6 & 2 & 4 \\
\hline (tourist) satisfaction & 5 & 3 & 2 \\
\hline (tourist) loyalty & 5 & 3 & 2 \\
\hline residents' attitudes & 5 & 2 & 3 \\
\hline community (tourism) benefits & 5 & 2 & 3 \\
\hline PLS-SEM technique & 4 & 1 & 3 \\
\hline destination image & 4 & 2 & 2 \\
\hline social capital & 3 & 2 & 1 \\
\hline experience economy & 3 & 1 & 2 \\
\hline sustainable livelihoods & 3 & 1 & 2 \\
\hline innovation & 3 & 1 & 2 \\
\hline food specialties & 3 & 0 & 3 \\
\hline
\end{tabular}

Source: Author's research

Following the example of Dimitrovski et al. (2019), in addition to the table view, a word cloud was also prepared "in order to provide a visual representation of the most frequently cited keywords and most frequent topics within the analyzed papers" (p. 31) (Figure 1). 
Figure 1. Word cloud of selected keywords

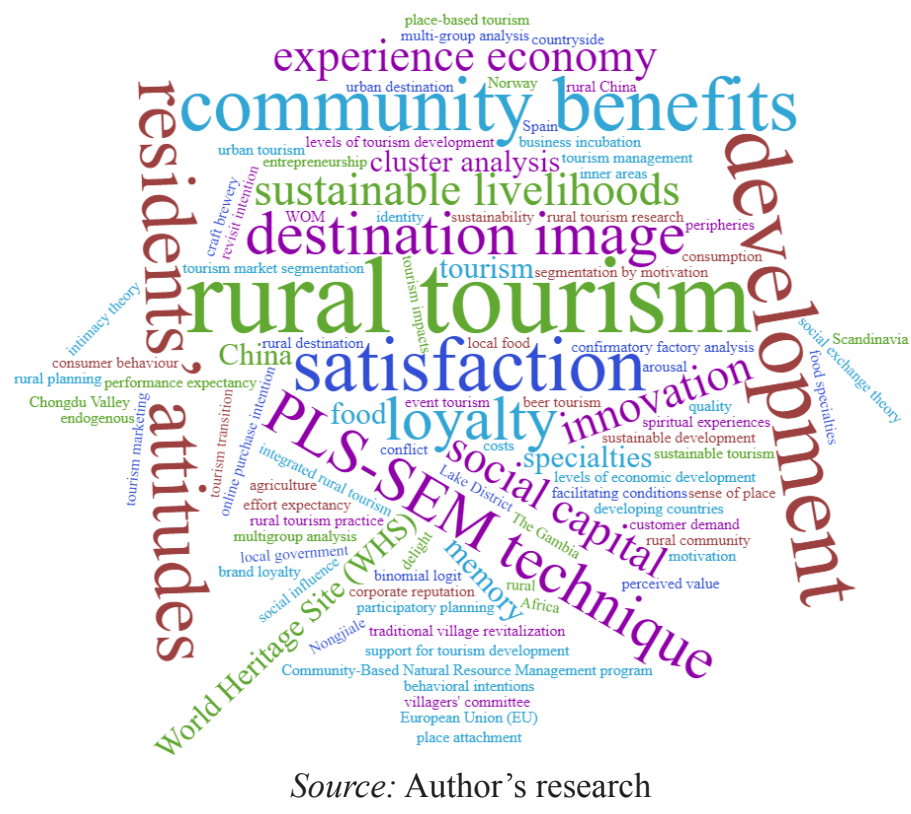

In addition to 'rural tourism' as expectedly the most common term, the previous table and graph show that issues of tourism development, tourist satisfaction and loyalty, attitudes and perceptions of the local population and community tourism benefits were the predominant research niches within the study area. Also, the authors paid significant attention to the image and promotion of the destination, the effects of social capital, experience economy, innovation and sustainable development. Among the keywords, the PLS-SEM technique stands out, which is along with the case study, the most frequently used research method. It is important to note that these research niches are almost equally represented in comparative subperiods, which speaks about the relatively steady interest of researchers and the need for a further and more dynamic development of scientific thought and intellectual structure of the subject area. The exception is the increased interest of researchers in culinary tourism (food tourism), based on local food specialities, which is evident in the second analyzed subperiod. It should be expected that, with an adequate marketing strategy, the specificity of local food will gain in importance as a factor of attracting tourists and therefore further production of papers on this topic can be expected.

After the acknowledgement of keywords analysis, a citation analysis was presented in Tables 5 and 6. The first part of the citation analysis was based on the distribution of Google Scholar and Scopus citations across the papers and aimed to identify the most impactful papers and authors that dominantly shape academic thought within the research area (Table 5). 
Table 5. Papers distribution of Google Scholar and Scopus citations

\begin{tabular}{|c|c|c|c|c|c|c|}
\hline \multirow{2}{*}{ Papers/Authors } & \multicolumn{3}{|c|}{ Google Scholar citations } & \multicolumn{3}{|c|}{ Scopus citations } \\
\hline & Total & $\begin{array}{c}\text { per } \\
\text { author }\end{array}$ & $\begin{array}{l}\text { per } \\
\text { year }\end{array}$ & Total & $\begin{array}{c}\text { per } \\
\text { author }\end{array}$ & $\begin{array}{c}\text { per } \\
\text { year }\end{array}$ \\
\hline $\begin{array}{l}\text { Campón-Cerro, A. M., Hernández-Mogollón, } \\
\text { J. M., \& Alves, H. (2017) }\end{array}$ & 109 & 36,33 & 36,33 & 41 & 13.67 & 13.67 \\
\hline $\begin{array}{c}\text { Devesa, M., Laguna, M., \& Palacios, A. } \\
\text { (2010) }\end{array}$ & 560 & 187,33 & 56 & 222 & 74 & 22.2 \\
\hline $\begin{array}{l}\text { Frisvoll, S., Forbord, M., \& Blekesaune, A. } \\
(2016)\end{array}$ & 73 & 24.33 & 18.25 & 43 & 14.33 & 10.75 \\
\hline Gao, J., \& Wu, B. (2017) & 138 & 69 & 46 & 71 & 35.5 & 23.67 \\
\hline $\begin{array}{c}\text { Hjalager, A., Kwiatkowski, G., \& Larsen, M. } \\
\varnothing . \text { (2018) }\end{array}$ & 51 & 17 & 25.5 & 33 & 11 & 16.5 \\
\hline $\begin{array}{c}\text { Kastenholz, E., Carneiro, M. J., Marques, C. } \\
\text { P., \& Loureiro, S. M. C. (2018) }\end{array}$ & 60 & 15 & 30 & 28 & 7 & 14 \\
\hline Lane, B., \& Kastenholz, E. (2015) & 172 & 86 & 34.4 & 77 & 38.5 & 15.4 \\
\hline Látková, P., \& Vogt, C. A. (2012) & 490 & 245 & 61.25 & 224 & 112 & 28 \\
\hline Loureiro, S. M. C., \& Kastenholz, E. (2011) & 336 & 168 & 37.33 & 158 & 79 & 17.56 \\
\hline Loureiro, S. M. C. (2014) & 355 & 355 & 59.17 & 181 & 181 & 30.17 \\
\hline Martín, H. S., \& Herrero, Á. (2012) & 491 & 245.5 & 61.38 & 242 & 121 & 30.25 \\
\hline Mbaiwa, J. E. \& Stronza, A. L. (2010) & 236 & 118 & 23.6 & 114 & 57 & 11.4 \\
\hline Murray, A., \& Kline, C. (2015) & 137 & 68.5 & 27.4 & 65 & 32.5 & 13 \\
\hline $\begin{array}{c}\text { Park, D.-B., Lee, K-W., Choi, H-S., \& Yoon, } \\
\text { Y.-S. (2012) }\end{array}$ & 171 & 42.75 & 21.38 & 80 & 20 & 10 \\
\hline $\begin{array}{c}\text { Park, D.-B., Nunkoo, R., \& Yoon, Y.-S. } \\
(2015)\end{array}$ & 91 & 30.33 & 18.2 & 51 & 17 & 10.2 \\
\hline $\begin{array}{l}\text { Phillips, W., Wolfe, K., Hodur, N., \& } \\
\text { Leistritz, F. L. (2013) }\end{array}$ & 197 & 49.25 & 28.14 & 82 & 20.5 & 11.71 \\
\hline $\begin{array}{l}\text { Rasoolimanesh, S. M., Roldan, J. L., Jaafar, } \\
\text { M., \& Ramayah, T. (2017a) }\end{array}$ & 84 & 21 & 28 & 50 & 12.5 & 16.67 \\
\hline $\begin{array}{l}\text { Rasoolimanesh, S. M., Ringle, C. M., } \\
\text { Jaafar, M., \& Ramayah, T. (2017b) }\end{array}$ & 185 & 46.25 & 61.67 & 103 & 25.75 & 34.33 \\
\hline $\begin{array}{l}\text { Rid, W., Ezeuduji, I. O., \& Pröbstl-Haider, U. } \\
(2014)\end{array}$ & 190 & 63.33 & 31.67 & 81 & 27 & 13.5 \\
\hline $\begin{array}{l}\text { Salvatore, R., Chiodo, E., \& Fantini, A. } \\
\text { (2018) }\end{array}$ & 51 & 17 & 25.5 & 26 & 8.67 & 13 \\
\hline Sharpley, R., \& Jepson, D. (2011) & 431 & 215.5 & 47.89 & 154 & 77 & 17.11 \\
\hline $\begin{array}{c}\text { Sidali, K., L., Kastenholz, E., \& Bianchi, R. } \\
(2015)\end{array}$ & 230 & 76.67 & 46 & 97 & 32.33 & 19.4 \\
\hline $\begin{array}{c}\text { Strzelecka, M., Boley, B. B., \& Strzelecka, C. } \\
(2017)\end{array}$ & 50 & 16.67 & 16.67 & 36 & 12 & 12 \\
\hline $\begin{array}{c}\text { Su, M. M., Wall, G., Wang, Y., \& Jin, M. } \\
(2019)\end{array}$ & 47 & 11.75 & 47 & 30 & 7.5 & 30 \\
\hline Wang, L., \& Yotsumoto, Y. (2019) & 35 & 17.5 & 35 & 17 & 8.5 & 17 \\
\hline Xue, L., Kerstetter, D., \& Hunt, C. (2017) & 58 & 19.33 & 19.33 & 33 & 11 & 11 \\
\hline $\begin{array}{l}\text { Zhao, W., Ritchie, J. R. B., \& Echtner, C. M. } \\
\text { (2011) }\end{array}$ & 223 & 74.33 & 24.78 & 106 & 35.33 & 11.78 \\
\hline
\end{tabular}

Source: Author's research 
The largest number of Google Scholar and Scopus citations were made by Martín and Herrero (2012), Látková and Vogt (2012) and Devesa et al. (2010). However, as the number of citations per year is a more relevant indicator of the impact of papers (Dimitrovski et al., 2019), the papers of Rasoolimanesh et al. (2017b), Martín and Herrero (2012) and Loureiro (2014) have mostly contributed to the modelling of scientific thought, having in mind the year of publication of the paper. The mentioned papers achieved over 30 Scopus citations per year, which is a desirable result having in mind the demanding criteria for referring literature sources in this index base. When it comes to individual authors, the most profound impact in the analyzed area in the last decade, both in terms of the number of published authorial and co-authorial papers and the number of realized citations, was referred to Professor Sandra Maria Correia Loureiro from the University of Aveiro in Portugal.

In the second part of the citation analysis, based on the distribution of Google Scholar and Scopus citations across the journals, the most influential sources of literature within the researched tourism specialism were identified (Table 6).

Table 6. Journals distribution of Google Scholar and Scopus citations

\begin{tabular}{|c|c|c|c|c|}
\hline \multirow{2}{*}{ Journal } & \multicolumn{2}{|c|}{ Google Scholar citations } & \multicolumn{2}{c|}{ Scopus citations } \\
\cline { 2 - 5 } & Total & per paper & Total & per paper \\
\hline Tourism Management & $\mathbf{1 , 8 1 7}$ & 227.13 & $\mathbf{8 4 6}$ & 105.75 \\
\hline Journal of Sustainable Tourism & 825 & 165 & 389 & 77.8 \\
\hline Annals of Tourism Research & 763 & 190.75 & 319 & 79.75 \\
\hline $\begin{array}{c}\text { Journal of Travel Research } \\
\text { International Journal of Hospitality } \\
\text { Management }\end{array}$ & 574 & 287 & 274 & 137 \\
\hline $\begin{array}{c}\text { Scandinavian Journal of Hospitality and } \\
\text { Tourism }\end{array}$ & 691 & $\mathbf{3 4 5 . 5}$ & 339 & $\mathbf{1 6 9 . 5}$ \\
\hline $\begin{array}{c}\text { Journal of Destination Marketing and } \\
\text { Management }\end{array}$ & 109 & 62 & 76 & 38 \\
\hline International Journal of Tourism Research & 197 & 109 & 41 & 41 \\
\hline Journal of Travel and Tourism Marketing & 60 & 60 & 28 & 82 \\
\hline Tourism Geographies & 91 & 91 & 51 & 51 \\
\hline
\end{tabular}

Source: Author's research

In line with the largest production of papers, the scientific journal Tourism Management also received the largest number of citations, which is not surprising considering the reputation and impact factor of this journal (IF 2019=7.432), which carries the epithet of the most influential journal in the field of tourism for years. However, it should be noted that the largest number of citations per paper was made by the International Journal of Hospitality Management, highlighting the enviable selection of papers by the journal review and editorial board. 


\section{Conclusions}

The review of contemporary literature on rural tourism published in the most prestigious tourism journals in the world and the evaluative bibliometric analysis conducted pointed to the following conclusions:

- In the last decade, the interest of the academic community has been mostly established and focused on issues of tourist satisfaction and loyalty, attitudes and perceptions of the local population, as well as on the crucial role of the management structure in recognizing, respecting and fulfilling the wishes and needs of tourists;

- Relatively stable interests of the authors indicate the need for more dynamic development of academic thought and structure of the subject area, and culinary tourism based on local food specialities, comparative analyses of rural tourism development and research of the impact of social capital on the development of this tourism activity stand out as insufficiently researched areas and potential directions of future research;

- When it comes to the geographical areas in which the research was conducted, there is a noticeable shift of interest of researchers from European to Asian countries, led by China, while among the research methods the most used are Case study and PLS-SEM technique;

- Bibliographic units that have made the outstanding contribution to modelling academic thought within the research area in the past decade are Rasoolimanesh et al. (2017b), Martín and Herrero (2012) and Loureiro (2014);

- The most productive and most cited member of the academic community whose focus is the discipline of rural tourism is Professor Sandra Maria Correia Loureiro from the University of Aveiro in Portugal;

- Among the sources of literature, the scientific journal Tourism Management takes the first place in terms of the number of published papers and citations. In contrast, the International Journal of Hospitality Management, has gathered the largest number of citations per paper, can be attributed as the most promising journal in the context of influence.

The theoretical contribution of the paper is reflected in the fact that, according to the cognitions of the authors, it is the first research of its kind conducted in the field of rural tourism. Also, the paper provides insight into recent trends in rural tourism literature, relatively stable interests of authors, insufficiently researched areas and possible directions of future research, acting as a generator of changes and further development of the rural tourism area. On the other hand, the identified growing interest of members of the academic community in culinary tourism sends a message to rural tourist destinations and tourism service providers to direct marketing activities to promote local food specialities that play an increasingly important role in attracting modern tourists. The above mentioned reflects the practical repercussions of the paper and the 
research realized in it. A fundamental limitation of the paper is the absence of relational bibliometric analysis and content analysis that would provide an even more in-depth insight into the researched issues. This limitation of a paper should serve as an idea for authors interested in future research in this area.

\section{Conflict of interests}

The authors declare no conflict of interest.

\section{References}

1. Blažević, M., Peters, K., \& Chen, G. (2018). Developing rural tourism in minority ethnic villages: Zlot and Xiaocang She Ethnic Township. Menadžment $u$ hotelijerstvu i turizmu - Hotel and Tourism Management, 6(2), 71-78. https://doi. org/10.5937/menhottur1802079B

2. Campón-Cerro, A. M., Hernández-Mogollón, J. M., \&Alves, H. (2017). Sustainable improvement of competitiveness in rural tourism destinations: The quest for tourist loyalty in Spain. Journal of Destination Marketing and Management, 6(3), 252 266. https://doi.org/10.1016/j.jdmm.2016.04.005

3. Cvijanović, D., Matijašević-Obradović, J., \& Škorić, S. (2017a). The Impact of Air Quality conditioned by emission of poluttants to the development of rural tourism and potentials of rural areas. Economics of Agriculture, 64(3), 871-885.

4. Cvijanović, D., Radović, G., \& Vojinović, Z. (2017b). Significance of the sustainable development of rural tourism in the Republic of Serbia. Zagadnienia Ekonomiki Rolnej, 2(351), 94-107. https://doi.org/10.5604/00441600.1240391

5. Devesa, M., Laguna, M., \& Palacios, A. (2010). The role of motivation in visitor satisfaction: Empirical evidence in rural tourism. Tourism Management, 31(4), 547-552. https://doi.org/10.1016/j.tourman.2009.06.006

6. Dimitrovski, D., Leković, M., \& Joukes, V. (2019). A bibliometric analysis of Crossref agritourism literature indexed in Web of Science. Menadžment $u$ hotelijerstvu i turizmu - Hotel and Tourism Management, 7(2), 25-37. https://doi. org/10.5937/menhottur1902025D

7. Evren, S., \& Kozak, N. (2013). Bibliometric analysis of tourism and hospitality related articles published in Turkey. Anatolia, 25(1), 61-80. https://doi.org/10.108 0/13032917.2013.824906

8. Frisvoll, S., Forbord, M., \& Blekesaune, A. (2016). An empirical investigation of tourists' consumption of local food in rural tourism. Scandinavian Journal of Hospitality and Tourism, 16(1), 76-93. https://doi.org/10.1080/15022250.2015.1 066918

9. Gao, J., \& Wu, B. (2017). Revitalizing traditional villages through rural tourism: A case study of Yuanjia Village, Shaanxi Province, China. Tourism Management, 63, 223-233. https://doi.org/10.1016/j.tourman.2017.04.003 
10. Hall, M. C. (2011). Publish and perish? Bibliometric analysis, journal ranking and the assessment of research quality in tourism. Tourism Management, 32(1), 16-27. https://doi.org/10.1016/j.tourman.2010.07.001

11. Hjalager, A., Kwiatkowski, G., \& Larsen, M. Ø. (2018). Innovation gaps in Scandinavian rural tourism. Scandinavian Journal of Hospitality and Tourism, 18(1), 1-17. https://doi.org/10.1080/15022250.2017.1287002

12. Kastenholz, E., Carneiro, M. J., Marques, C. P., \& Loureiro, S. M. C. (2018). The dimensions of rural tourism experience: Impacts on arousal, memory, and satisfaction. Journal of Travel and Tourism Marketing, 35(2), 189-201. https://doi. org/10.1080/10548408.2017.1350617

13. Koseoglu, M. A., Rahimi, R., Okumus, F., \& Liu, J. (2016). Bibliometric studies in tourism. Annals of Tourism Research, 61, 180-198. https://doi.org/10.1016/j. annals.2016.10.006

14. Lane, B., \& Kastenholz, E. (2015). Rural tourism: The evolution of practice and research approaches - towards a new generation concept?. Journal of Sustainable Tourism, 23(8), 1133-1156. https://doi.org/10.1080/09669582.2015.1083997

15. Látková, P., \& Vogt, C. A. (2012). Residents' attitudes toward existing and future tourism development in rural communities. Journal of Travel Research, 51(1), 5067. https://doi.org/10.1177/0047287510394193

16. Loureiro, S. M. C., \& Kastenholz, E. (2011). Corporate reputation, satisfaction, delight, and loyalty towards rural lodging units in Portugal. International Journal of Hospitality Management, 30(3), 575-583. https://doi.org/10.1016/j. ijhm.2010.10.007

17. Loureiro, S. M. C. (2014). The role of the rural tourism experience economy in place attachment and behavioral intentions. International Journal of Hospitality Management, 40, 1-9. https://doi.org/10.1016/j.ijhm.2014.02.010

18. Martín-Martín, A., Orduna-Malea, E., Thelwall, M., \& López-Cózar, E. D. (2018). Google Scholar, Web of Science, and Scopus: A systematic comparison of citations in 252 subject categories. Journal of Informetrics, 12(4), 1160-1177. https://doi. org/10.31235/osf.io/42nkm

19. Martín, H. S., \& Herrero, Á. (2012). Influence of the user's psychological factors on the online purchase intention in rural tourism: Integrating innovativeness to the UTAUT framework. Tourism Management, 33(2), 341-350. https://doi. org/10.1016/j.tourman.2011.04.003

20. Mbaiwa, J. E. \& Stronza, A. L. (2010). The effects of tourism development on rural livelihoods in the Okavango Delta, Botswana. Journal of Sustainable Tourism, 18(5), 635-656. https://doi.org/10.1080/09669581003653500

21. Murray, A., \& Kline, C. (2015). Rural tourism and the craft beer experience: Factors influencing brand loyalty in rural North Carolina, USA. Journal of Sustainable Tourism, 23(8), 1198-1216. https://doi.org/10.1080/09669582.2014.987146 
22. Nusair, K., Butt, I., \& Nikhashemi, S. R. (2019). A bibliometric analysis of social media in hospitality and tourism research. International Journal of Contemporary Hospitality Management, 31(7), 2691-2719. https://doi.org/10.1108/ ijchm-06-2018-0489

23. Park, D.-B., Lee, K-W., Choi, H-S., \& Yoon, Y.-S. (2012). Factors influencing social capital in rural tourism communities in South Korea. Tourism Management, 33(6), 1511-1520. https://doi.org/10.1016/j.tourman.2012.02.005

24. Park, D.-B., Nunkoo, R., \& Yoon, Y.-S. (2015). Rural residents' attitudes to tourism and the moderating effects of social capital. Tourism Geographies, 17(1), 112-133. https://doi.org/10.1080/14616688.2014.959993

25. Phillips, W., Wolfe, K., Hodur, N., \& Leistritz, F. L. (2013). Tourist word of mouth and revisit intentions to rural tourism destinations: A case of North Dakota, USA. International Journal of Tourism Research, 15(1), 93-104. https://doi.org/10.1002/ jtr.879

26. Rasoolimanesh, S. M., Roldan, J. L., Jaafar, M., \& Ramayah, T. (2017a). Factors influencing residents' perceptions toward tourism development: Differences across rural and urban world heritage sites. Journal of Travel Research, 56(6), 760-775. https://doi.org/10.1177/0047287516662354

27. Rasoolimanesh, S. M., Ringle, C. M., Jaafar, M., \& Ramayah, T. (2017b). Urban vs. rural destinations: Residents' perceptions, community participation and support for tourism development. Tourism Management, 60, 147-158. https://doi. org/10.1016/j.tourman.2016.11.019

28. Rid, W., Ezeuduji, I. O., \& Pröbstl-Haider, U. (2014). Segmentation by motivation for rural tourism activities in The Gambia. Tourism Management, 40, 102-116. https://doi.org/10.1016/j.tourman.2013.05.006

29. Salvatore, R., Chiodo, E., \& Fantini, A. (2018). Tourism transition in peripheral rural areas: Theories, issues and strategies. Annals of Tourism Research, 68, 41-51. https://doi.org/10.1016/j.annals.2017.11.003

30. Sharpley, R., \& Jepson, D. (2011). Rural tourism A spiritual experience?. Annals of Tourism Research, 38(1), 52-71. https://doi.org/10.1016/j.annals.2010.05.002

31. Sidali, K., L., Kastenholz, E., \& Bianchi, R. (2015). Food tourism, niche markets and products in rural tourism: Combining the intimacy model and the experience economy as a rural development strategy. Journal of Sustainable Tourism, 23(8), 1179-1197. https://doi.org/10.1080/09669582.2013.836210

32. Strzelecka, M., Boley, B. B., \& Strzelecka, C. (2017). Empowerment and resident support for tourism in rural Central and Eastern Europe (CEE): The case of Pomerania, Poland. Journal of Sustainable Tourism, 25(4), 554-572. https://doi.or $\mathrm{g} / 10.1080 / 09669582.2016 .1224891$ 
33. Su, M. M., Wall, G., Wang, Y., \& Jin, M. (2019). Livelihood sustainability in a rural tourism destination - Hetu Town, Anhui Province, China. Tourism Management, 71, 272-281. https://doi.org/10.1016/j.tourman.2018.10.019

34. Wang, L., \& Yotsumoto, Y. (2019). Conflict in tourism development in rural China. Tourism Management, 70, 188-200. https://doi.org/10.1016/j.tourman.2018.08.012

35. Xue, L., Kerstetter, D., \& Hunt, C. (2017). Tourism development and changing rural identity in China. Annals of Tourism Research, 66, 170-182. https://doi. org/10.1016/j.annals.2017.07.016

36. Zhao, W., Ritchie, J. R. B., \& Echtner, C. M. (2011). Social capital and tourism entrepreneurship. Annals of Tourism Research, 38(4), 1570-1593. https://doi. org/10.1016/j.annals.2011.02.006 